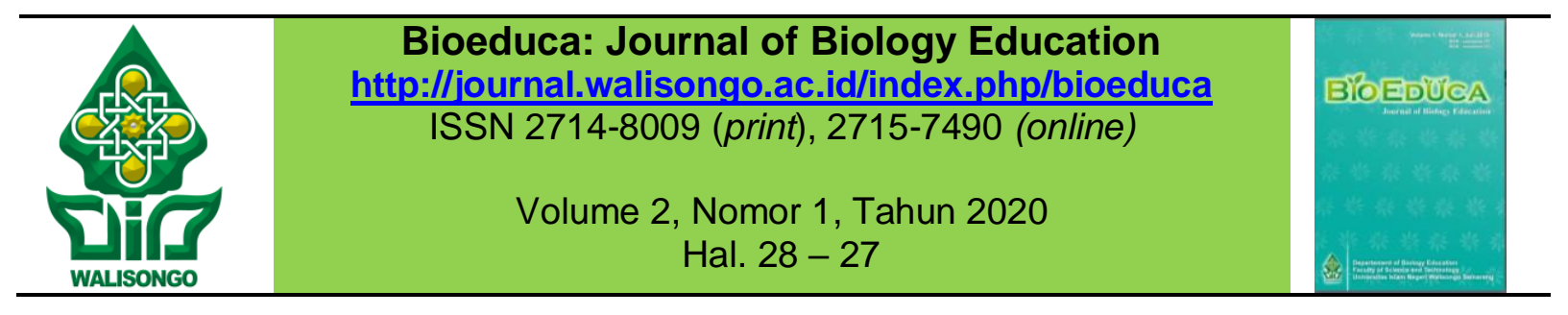

\title{
Pengembangan Four-Tier Multiple Choice Diagnostic Test untuk Mendeteksi Pemahaman Konsep Kognitif Materi Katabolisme pada Peserta Didik Kelas XII SMA / MA
}

\begin{tabular}{|c|c|}
\hline \multicolumn{2}{|c|}{$\begin{array}{c}\text { Umi Salamah }{ }^{\mathbf{1}^{\star}} \text {, Nur Khasanah }{ }^{\mathbf{2}} \text {, Nur Hayati }{ }^{\mathbf{3}} \\
{ }_{1,2,3} \text { Pendidikan Biologi, Universitas Islam Negeri Walisongo Semarang } \\
{ }^{*} \text { Email: salamah26umi@gmail.com }\end{array}$} \\
\hline Informasi Artikel & ABSTRAK \\
\hline $\begin{array}{l}\text { Submit: } 10-09-2019 \\
\text { Diterima: } 12-12-2019 \\
\text { Dipublikasikan: } 12-03-2020\end{array}$ & $\begin{array}{l}\text { Penelitian ini bertujuan mengembangkan tes untuk mendeteksi } \\
\text { miskonsepsi pada materi katabolisme. Pengembangan produk } \\
\text { mengikuti Borg and Gall sampai tahap ke-7. Subjek uji coba } \\
\text { adalah siswa MAN } 2 \text { Semarang. Data diambil melalui } \\
\text { wawancara, tes, pengisian angket, dan dokumentasi. Analisis } \\
\text { produk secara kualitatif oleh validator ahli. Secara kuantitatif } \\
\text { dengan menghitung nilai validitas, reliabilitas, tingkat kesukaran, } \\
\text { daya pembeda, keberfungsian pengecoh, analisis miskonsepsi, } \\
\text { dan interpretasi hasil. Instrumen yang dihasilkan dinyatakan } \\
\text { valid. Reliabilitas butir soal yang dikembangkan masuk kategori } \\
\text { tinggi yaitu sebesar } 0,894 \text {. Sebanyak } 37 \text { butir soal dihasilkan } \\
\text { terdiri dari } 4 \text { butir soal mudah, } 24 \text { butir soal sedang, dan } 9 \text { butir } \\
\text { soal susah. Butir soal memiliki daya beda dengan kategori } 4 \text { butir } \\
\text { soal cukup baik dan } 33 \text { butir soal baik. Sebanyak } 18 \text { indikator } \\
\text { soal ditemukan terjadi miskonsepsi. Miskonsepsi tertinggi pada } \\
\text { konsep analisis peran enzim sedangkan terendah pada konsep } \\
\text { analisis peran ATP dan perubahan molekul saat transpor } \\
\text { elektron dan fosforilasi oksidatif. } \\
\text { Kata kunci: four-tier multiple choice diagnostic test, katabolisme, } \\
\text { pemahaman konsep kognitif, miskonsepsi. }\end{array}$ \\
\hline Penerbit & ABSTRACT \\
\hline $\begin{array}{l}\text { Program Studi Pendidikan } \\
\text { Biologi, Fakultas Sains dan } \\
\text { Teknologi, UIN Walisongo } \\
\text { Semarang }\end{array}$ & $\begin{array}{l}\text { This study developed a test to detect misconceptions in } \\
\text { catabolism concept. Product development followed Borg and Gall } \\
\text { through to the 7th stage. Subjects were students of MAN } 2 \\
\text { Semarang. Data were collected through interviews, tests, } \\
\text { questionnaires, and documentation. Qualitative product analysis } \\
\text { by expert validators. Quantitatively, by calculating the value of } \\
\text { validity, reliability, level of difficulty, distinguishing power, } \\
\text { distractor function, analysis of misconceptions, and interpretation } \\
\text { of results. The instrument was declared valid. The reliability was } \\
\text { in the high category, 0.894. A total of } 37 \text { items were generated } \\
\text { consisting of } 4 \text { easy items, } 24 \text { medium questions, and } 9 \text { difficult } \\
\text { items. The items have different power with the } 4 \text { item categories } \\
\text { being quite good and } 33 \text { items being good. Misconception was } \\
\text { found at } 18 \text { questions. The highest misconception was found at } \\
\text { analysis of the role of enzymes concept, while the lowest is the } \\
\text { analyzing the role of ATP and molecular changes during electron } \\
\text { transport and oxidative phosphorylation concept. } \\
\text { Keywords: Four-tier multiple choice diagnostic test, catabolism } \\
\text { understanding cognitive concepts, misconceptions. }\end{array}$ \\
\hline
\end{tabular}

Copyright (O2020, Bioeduca: Journal of Biology Education

Umi Salamah et al. - Pengembangan Four-Tier Multiple Choice Diagnostic Test untuk Mendeteksi Pemahaman Konsep Kognitif Materi Katabolisme pada 


\section{PENDAHULUAN}

Biologi merupakan cabang ilmu IPA yang mempelajari konsep-konsep ilmiah mengenai kehidupan makhluk hidup, baik interaksi antar makhluk hidup maupun proses yang terjadi dalam makhluk hidup itu sendiri (Mustaqim et al., 2014). Katabolisme adalah materi Biologi yang didalamnya memuat konsep dasar yang berhubungan dengan konsep materi Biologi yang lain. Katabolisme menjadi dasar untuk mempelajari materi yang lain, seperti dalam fisiologi hewan, fisiologi tumbuhan, dan bioteknologi, Materi ini agak sulit dipahami peserta didik, karena masih asing dan baru diajarkan oleh pendidik. Kesulitan tersebut membuat kekhawatiran bagi pendidik, sehingga sebelum peserta didik memasuki ke jenjang yang lebih tinggi diharapkan sudah memiliki pengetahuan awal tentang konsep katabolisme dengan baik (Rahmatan dan Lilianasari, 2012).

Pemahaman dan penguasaan konsep biologi sangat diperlukan untuk pengintegrasian alam dan teknologi dalam kehidupan sehari-hari. Dari pemahaman dan penguasaan tersebut diharapkan peserta didik mampu mendeskripsikan dan menghubungkan antar konsep untuk menjelaskan peristiwa-peristiwa alam yang terjadi dalam kehidupan sehari-hari (Tambunan, 2015).

Pemahaman kognitif diperlukan peserta didik untuk dapat berpikir. Tanpa kemampuan berpikir mustahil peserta didik dapat memahami dan meyakini faedah materi-materi pelajaran yang disajikan kepadanya (Syah, 2014). Peserta didik banyak yang terjerumus ke dalam pemahaman mereka sendiri, apalagi dalam bidang biologi yang didalamnya terdapat banyak istilah-istilah asing yang susah dipahami. Pemahaman mereka tentang biologi ini, biasa dikontruksi dari pengalaman sehari-hari. Mereka menganggap pemahaman yang didapatkan seolah-olah sudah benar secara konsep, padahal pemahaman tersebut belum tentu benar secara konsep. Pemahaman yang belum tentu benar secara konsep ini jika dibiarkan akan dibawa ke jenjang pendidikan yang lebih tinggi dan membentuk rantai panjang miskonsepsi yang semakin luas persebarannya (Tekkaya, 2002). Konsep awal yang tidak sesuai dengan konsep ilmiah ini disebut miskonsepsi (Suparno, 2005).

Hasil observasi dan wawancara yang telah dilakukan peneliti dengan guru pengampu mata pelajaran Biologi MAN 2 Semarang tahun 2018, menunjukkkan bahwa guru menganggap sebagian besar peserta didik sudah memahami katabolisme, yang ditandai dengan nilai hasil belajar peserta didik yang berada diatas KKM. Hasil wawancara yang telah dilakukan peneliti dengan beberapa peserta didik kelas XII IPA MAN 2 Semarang tahun 2018 menunjukkan hasil yang berbeda, yakni banyak peserta didik memberikan respon jawaban yang berbeda-beda dengan tingkat keyakinan yang berbeda pula. Anggapan guru tentang pemahaman peserta didik dengan hasil belajar peserta didik dan respon jawaban peserta didik yang berbedabeda tersebut mempunyai kemungkinan peserta didik tersebut mengalami ketidaktahuan konsep bahkan mengalami miskonsepsi yang belum diketahui oleh guru. Adanya kesalahan tulisan pada sumber belajar (buku LKS) yang dipakai oleh peserta didik dalam pembelajaran materi katabolisme juga mengungkapkan bahwa kemungkinan besar peserta didik tersebut mengalami miskonsepsi yang belum 
diketahui oleh guru. Kebanyakan guru cenderung tidak pernah melakukan tes untuk mendeteksi miskonsepsi yang terjadi pada peserta didik. Penyusunan instrumen tes untuk mendeteksi adanya miskonsepsi ini sangat penting, agar guru dapat mengidentifikasi kesalahan konsep peserta didik dan dapat mempermudah guru untuk memberikan treatment khusus untuk mengatasi miskonsepsi tersebut.

Cara-cara yang digunakan untuk mendeteksi miskonsepsi siswa, antara lain: wawancara, peta konsep, tes esai, tes pilihan ganda dengan alasan, diskusi di kelas, dan praktikum (Suparno, 2005). Bentuk-bentuk tes diagnostik pilihan ganda telah dikembangkan dengan berbagai tingkatan (tier), yaitu: tes diagnostik pilihan ganda dua tingkat (two-tier), tiga tingkat (three-tier), dan empat tingkat (four-tier). Macam-macam tes diagnostik tersebut memiliki kelebihan dan kekurangan masing-masing, seperti tes diagnostik pilihan ganda tiga tingkat yang masih mempunyai kelemahan yaitu tidak dapat mendeteksi tingkat keyakinan peserta didik yang berbeda dalam memilih pilihan jawaban dan pilihan alasan, sehingga belum bisa mengkategorikan mana peserta didik yang kurang pengetahuan, mana peserta didik yang tidak paham konsep, mana peserta didik yang paham konsep, dan mana peserta didik yang mengalami miskonsepsi (Gurel et al., 2015).

Tes diagnostik untuk mendeteksi pemahaman konsep peserta didik sudah pernah dikembangkan oleh Suwarto (2010). Namun, pengembangan tes diagnostik tersebut masih menggunakan dua tingkatan (two-tier). Selain itu pengembangan tes diagnostik juga baru dilakukan untuk materi tingkat keanekaragaman dalam kehidupan, biodiversitas di Indonesia, plantae. porifera, coelenterata, plathyhelminthes, nemathelminthes, annelida, mollusca, arthropoda, echinodermata, chordata, ekosistem, aliran energi, daur biogeokimia, pencemaran lingkungan dan pelestarian lingkungan, jenis limbah dan daur ulang limbah. Sehingga perlu dikembangkan instrumen tes diagnostik untuk materi katabolisme. Hal ini juga dikarenakan materi metabolisme sangat rawan terhadap miskonsepsi pemahaman siswa.

Berdasarkan uraian tersebut dirumuskan permasalahan dalam penelitian ini adalah bagaimana karakteristik four-tier multiple choice diagnostic test materi katabolisme untuk mendeteksi pemahaman konsep kognitif pada peserta didik kelas XII SMA/MA dan apa saja miskonsepsi pemahaman konsep kognitif yang terdeteksi dengan four-tier multiple choice diagnostic test materi katabolisme pada peserta didik kelas XII SMA/MA.

\section{METODE PENELITIAN}

Metode penelitian yang digunakan adalah metode Research and Development $(R \& D)$. Metode ini merupakan metode penelitian yang digunakan untuk menghasilkan produk tertentu, dan menguji kefektifan produk tersebut (Sugiyono, 2015). Selain menghasilkan produk, penelitian $R \& D$ juga menyempurnakan produk yang sudah ada (Sukmadinata dalam Haryati, 2012). Model pengembangan yang digunakan yaitu model pengembangan yang diadaptasi dari model pengembangan Borg \& Gall (2003) dengan modifikasi. Tahapan model pengembangan ini terdiri dari 7 langkah, yaitu 
penelitian dan pengumpulan informasi awal, perencanaan pembuatan produk, pengembangan produk awal, uji coba skala kecil, revisi produk, uji coba skala besar, revisi produk. Tahapan pengembangan produk awal dilakukan berdasarkan langkah Fariyani (2015), yaitu analisis KI (Kompetensi Inti) dan KD (Kompetensi Dasar), penyusunan kisi-kisi soal tes, penulisan butir soal, penelaahan butir soal dan revisi butir soal.

Subjek penelitian ini adalah 20 orang peserta didik kelas XII MIPA 1 MAN 2 Semarang pada uji coba skala kecil, dan 74 orang peserta didik pada uji coba skala besar yang terdiri dari 36 orang peserta didik kelas XII MIPA 2 dan 38 orang peserta didik kelas XII MIPA 4 MAN 2 Semarang.

Metode pengumpulan data dilakukan melalui: wawancara, tes, pengisian angket respon peserta didik, dan dokumentasi. Wawancara dilakukan sebanyak dua kali, yaitu pra riset dan pasca riset. Wawancara pra riset dilakukan pada peserta didik dan guru. Wawancara pra riset digunakan untuk tahap analisis kebutuhan pengembangan produk dan mengetahui tingkat pengetahuan guru tentang instrumen diagnostik. Wawancara pasca riset hanya dilakukan pada guru. Wawancara pasca riset bertujuan untuk mendapatkan tanggapan guru terhadap instrumen yang telah dikembangkan.

Analisis produk dilakukan secara kualitatif dan kuantitatif. Secara kualitatif dilakukan oleh validator ahli (ahli materi dan ahli evaluasi) dengan menelaah setiap butir soal dari berbagai aspek, yaitu aspek materi, konstruksi, bahasa, kunci jawaban, dan pedoman penskoran. Secara kuantitatif dilakukan dengan menghitung nilai validitas, reliabilitas, tingkat kesukaran, daya pembeda, keberfungsian pengecoh, analisis miskonsepsi dengan CDQ, dan interpretasi hasil. Uji reliabilitas dihitung dengan menggunakan rumus Alpha Cronbach. Analisis miskonsepsi peserta didik menggunakan persamaan CDQ (Confidence Discrimination Quotient), sama seperti yang digunakan oleh Caleon \& Subramaniam (2010) pada soal four-tier diagnostic test (FTDT) dengan menggunakan rumus CDQ.

$$
C D Q=\frac{C F C-C F W}{\begin{array}{c}
\text { Standar deviasi tingkat keyakinan peserta didik } \\
\text { dalam memilih jawaban atau alasan }
\end{array}}
$$

CFC $($ Confidence Correct $)=$ rata-rata tingkat keyakinan peserta didik yang menjawab benar.

CFW (Confidence Wrong) = rata-rata tingkat keyakinan peserta didik yang menjawab salah.

Interpretasi hasil digunakan untuk menggolongkan peserta didik dalam kategori paham, tidak paham, dan miskonsepsi.

\section{HASIL PENELITIAN DAN PEMBAHASAN}

\section{Karakteristik four-tier multiple choice diagnostic test materi katabolisme}

Penelitian ini difokuskan pada pengembangan produk berupa instrumen four-tier multiple choice diagnostic test materi katabolisme kelas XII SMA / MA. Produk instrumen yang dikembangkan dapat digunakan sebagai alat evaluasi untuk mendeteksi kesalahan pemahaman aspek kognitif pada materi katabolisme kelas XII 
SMA/MA. Produk yang dihasilkan dari penelitian ini meliputi kisi-kisi soal, soal pilihan ganda dengan alasan semi terbuka, petunjuk pengerjaan soal, petunjuk pengisian lembar jawaban, lembar jawaban, kunci jawaban, pedoman penskoran, dan pedoman interpretasi hasil jawaban.

Kisi-kisi soal disusun dengan berpedoman pada Kompetensi Inti $(\mathrm{KI})$ dan Kompetensi Dasar (KD) kurikulum 2013. Kisi-kisi soal tes yang dikembangkan memuat Kompetensi Inti (KI), Kompetensi Dasar (KD), indikator soal dan kategori kognitif soal (menggunakan taksonomi Bloom; C1, C2,C3, dan C4), nomor soal, dan jumlah butir soal.

Petunjuk pengerjaan soal dibuat agar peserta didik mengetahui langkah dan aturan yang jelas untuk mengerjakan soal. terdapat 12 poin tentang cara mengerjakan soal, aturan dan larangan saat mengerjakan soal, dan cara pengumpulan lembar soal dan lembar jawab agar tes dapat berjalan tertib.

Soal four-tier multiple choice diagnostic test materi katabolisme ditulis dengan berpedoman pada format penulisan soal four-tier multiple choice diagnostic test yang dikembangkan oleh Caleon \& Subramaniam (2010), yaitu tersusun atas empat tingkatan. Tingkat pertama berupa pokok soal dan 5 pilihan jawaban, tingkat kedua berupa tingkat keyakinan jawaban, tingkat ketiga berupa pilihan alasan, dan tingkat keempat berupa tingkat keyakinan alasan. Pokok soal berisi pertanyaan dengan 4 jawaban pengecoh dan 1 jawaban benar. Pilhan alasan berisi 3 alasan pengecoh dan 1 alasan benar, serta 1 alasan terbuka. Tingkat keyakinan jawaban dan alasan terdiri dari 6 pilihan tingkatan yaitu, (1) hanya menebak, (2) sangat tidak yakin, (3) tidak yakin, (4) yakin, (5) sangat yakin, (6) amat sangat yakin.

Produk awal soal four-tier multiple choice diagnostic test materi katabolisme terdiri atas 50 butir soal meliputi 9 sub pokok bahasan dengan 25 indikator. Produk akhir soal four-tier multiple choice diagnostic test materi katabolisme adalah 37 butir soal. reduksi soal tersebut dilakukan setelah produk awal diuji cobakan pada skala kecil meliputi 9 pokok sub bahasan dan 25 indikator butir soal.

Kunci jawaban soal four-tier multiple choice diagnostic test materi katabolisme. Kunci jawaban dibuat untuk mempermudah koreksi soal, digunakan sebagai pedoman penskoran atas pilihan jawaban peserta didik dan juga untuk analisis hasil tes.

Petunjuk pengisian lembar jawaban dibuat agar peserta didik mengetahui langkah-langkah dalam mengisi jawaban pada lembar jawaban. Petunjuk pengisian lembar jawaban berisi judul, contoh tabel yang ada di lembar jawab soal, dan penjelasan tabel.

Lembar jawaban disusun untuk mempermudah peserta didik dalam menuliskan jawaban saat mengerjakan soal tes, dan juga mempermudah peneliti dalam menganalisis jawaban peserta didik. Lembar jawaban soal four-tier multiple choice diagnostic test materi katabolisme berisi judul, nama, nomor absen, kelas, dan tabel yang terdiri dari lima buah kolom, yaitu kolom nomor soal, kolom pilihan jawaban, kolom pilihan tingkat keyakinan jawaban, kolom pilihan alasan, dan kolom pilihan tingkat keyakinan alasan. Halaman khusus juga disediakan dibalik lembar kolom, 
untuk menuliskan alasan terbuka apabila peserta didik merasa tidak ada pilihan alasan yang benar.

Pedoman penskoran four-tier multiple choice diagnostic test materi katabolisme dibuat untuk dijadikan acuan dalam memberikan skor hasil tes yang telah dikerjakan oleh peserta didik. Pedoman penskoran yang telah dibuat digunakan untuk menentukan skor atas jawaban dan alasan yang dipilih peserta didik. Skor 1 diberikan jika jawaban atau alasan yang dipilih benar, sedangkan jika skor 0 diberikan jawaban atau alasan yang dipilih salah.

Pedoman interpretasi hasil jawaban. Pedoman interpretasi hasil jawaban peserta didik dibuat untuk dijadikan acuan dalam menggolongkan peserta didik. Pedoman interpretasi hasil jawaban peserta didik yang telah dibuat digunakan dalam mengkategorikan peserta didik antara paham, tidak paham, atau miskonsepsi. Pedoman interpretasi hasil jawaban peserta didik tersusun atas judul, dan tabel yang teridri dari 5 kolom yaitu kolom jawaban, kolom tingkat keyakinan jawaban, kolom alasan, kolom tingkat keyakinan alasan, dan kolom kategori. Tingkat keyakinan tergolong tinggi, jika dipilih dengan skala empat, lima, dan enam. Tingkat keyakinan tergolong rendah, jika dipilih dengan skala satu, dua, dan tiga.

Sebelum diuji cobakan produk tersebut dilakukan validasi untuk mengetahui validitas produk tersebut. Validasi produk dilakukan pada dua ahli materi dan dua ahli evaluasi. Rekapitulasi hasil analisis validasi instrumen soal secara garis besar dapat dilihat pada Tabel 1.

Tabel 1. Rekapitulasi Hasil Analisis Validasi Instrumen Soal Oleh Validator

\begin{tabular}{ccccc}
\hline Validator & Jumlah Skor & $\begin{array}{c}\text { Rata-rata } \\
\text { Skor }\end{array}$ & $\begin{array}{c}\text { Persentase Total } \\
\text { Rata-Rata Skor }\end{array}$ & Kriteria \\
\hline Ahli Materi I & 4396 & 87,9 & 76,5 & CV \\
Ahli Materi II & 4814 & 96,3 & 83,7 & CV \\
Ahli Evaluasi I & 4057 & 81,1 & 70,6 & CV \\
Ahli Evaluasi II & 4791 & 95,8 & 83,3 & CV \\
\hline Jumlah & 18058 & 90,3 & 78,3 & CV \\
\hline
\end{tabular}

Kriteria persentase kevalidan sebagai berikut (Akbar, 2013):

Persentase $85,01 \%-100 \%=$ Sangat Valid

Persentase $70,01 \%-85 \%=$ Cukup Valid

Persentase $50,01 \%-70 \%=$ Kurang Valid

Persentase $0,1 \%-50 \%=$ Tidak Valid

Berdasarkan Tabel 1 menunjukkan bahwa instrumen soal four-tier multiple choice diagnostic test materi katabolisme cukup valid untuk digunakan. Kevalidan ini dilihat dari persentase total rata-rata skor semua validator yang mendapat nilai $78,3 \%$. Kategori cukup valid ini berarti instrumen soal bisa digunakan dengan sedikit revisi.

\section{Karakteristik butir soal four-tier multiple choice diagnostic test materi katabolisme}

Karakteristik butir soal four-tier multiple choice diagnostic test materi katabolisme yang dikembangkan meliputi validitas, reliabilitas, tingkat kesukaran, daya beda, dan keberfungsian pengecoh.

Umi Salamah et al. - Pengembangan Four-Tier Multiple Choice Diagnostic Test untuk Mendeteksi Pemahaman Konsep Kognitif Materi Katabolisme pada 
Dari 50 butir soal yang diuji cobakan pada skala kecil terdapat 40 butir soal valid dan 10 butir soal tidak valid. Dari 40 butir soal yang diuji cobakan pada skala besar terdapat 37 butir soal valid dan 3 butir soal tidak valid.

Hasil analisis reliabilitas butir soal menunjukkan soal tersebut reliabel dengan nilai Alpha Cronbach sebesar 0,942 pada uji coba skala kecil dan 0,894 pada uji coba skala besar lebih besar dari rabel.

Hasil analisis 50 butir soal pada uji coba skala kecil terdapat 4 butir soal mudah, 34 butir soal sedang, dan 12 butir soal sukar dengan angka tingkat kesukaran sebesar 0,22 sampai 0,72 . Hasil analisis 40 butir soal pada uji coba skala besar terdapat 4 butir soal mudah, 26 butir soal sedang, dan 10 butir soal sukar dengan angka tingkat kesukaran sebesar 0,28 sampai 0,78 . Secara gais besar soal yang dikembangkan termasuk sedang. Menurut Wahidmurni dalam Wijaya, dkk (2013), taraf kesukaran untuk tes diagnostik adalah sedang, maka tes diagnostik hasil pengembangan ini memenuhi syarat sebagai tes diagnostik.

Hasil analisis daya beda uji coba skala kecil mempunyai indeks daya beda soal dari 0,2 sampai 0,5 . Dari 50 butir soal terdapat 1 butir soal yang mempunyai nilai daya beda dengan kategori jelek. 13 butir soal yang mempunyai nilai daya beda cukup. 36 butir soal yang mempunyai nilai daya beda baik. Hasil analisis daya beda uji skala besar mempunyai indeks daya beda soal dari 0,29 sampai 0,69 . 40 butir soal terdapat 3 butir soal yang mempunyai nilai daya beda cukup, dan 36 butir soal yang mempunyai nilai daya beda baik. Indeks daya beda hasil analisis uji coba skala kecil dan skala besar yang mempunyai nilai positif menunjukkan bahwa butir soal dapat digunakan dalam instrumen tes diagnostik tersebut. Menurut Suwarto (2013), daya beda pada butir soal tes diagnostik digunakan untuk menjamin tidak adanya daya beda negatif pada butir tes. Butir soal yang mempunyai daya beda negatif harus dieliminasi dari sebuah tes.

Pengecoh berfungsi baik jika dipilih oleh subjek minimal sebanyak $5 \%$ dari jumlah seluruh subjek. (Arikunto, 2013). Berdasarkan analisis pada uji coba skala besar, dari 40 soal terdapat 9 soal pada pilihan jawaban yang pengecohnya tidak berfungsi, karena dipilih kurang dari $5 \%$ seluruh peserta didik yang melaksanakan tes.

\section{Temuan Miskonsepsi}

Miskonsepsi yang terjadi pada peserta didik dapat ditemukan dengan menganalisis hasil tes peserta didik melalui nilai CDQ (Confidence Diskrimination Quotient). Jika nilai CDQ negatif, maka peserta didik tidak dapat membedakan apa yang mereka pahami dan tidak mereka pahami atau peserta didik mengalami miskonsepsi (Fariyani, 2015). Nilai CDQ diperoleh dari analisis pilihan jawaban, alasan dan keduanya dalam 40 butir soal yang dikerjakan oleh 74 peserta didik pada uji coba skala besar. Nilai CDQ yang diperoleh dari analisis data adalah sebesar - 4,84 sampai 2,4. Rekapitulasi hasil temuan miskonsepsi disajikan pada Tabel 2.

Berdasarkan Tabel 2, menunjukkan bahwa peserta didik terdeteksi mengalami miskonsepsi pada 12 butir soal tingkat jawaban dan , 19 butir soal tingkat alasan, dan 17 butir soal keduanya (jawaban dan alasan), dan tidak mengalami miskonsepsi pada 
28 butir soal tingkat jawaban, 21 butir soal tingkat alasan, dan 23 butir soal keduanya (jawaban dan alasan). Peserta didik yang mengalami miskonsepsi ditunjukkan dengan nilai CDQ bernilai negatif, sedangkan peserta didik yang tidak mengalami miskonsepsi ditunjukkan dengan nilai CDQ positif. Peserta didik yang tidak mengalami miskonsepsi mempunyai dua kemungkinan, yaitu peserta didik benar-benar paham konsep atau peserta didik tidak paham konsep.

Tabel 2. Rekapitulasi Hasil Analisis Miskonsepsi Peserta Didik Dengan CDQ

\begin{tabular}{cccc}
\hline Nilai & \multicolumn{3}{c}{ Nomor Soal } \\
\cline { 2 - 4 } CDQ & Jawaban & Alasan & Keduanya \\
\hline \multirow{2}{*}{ CDQ $<0$} & $2,3,5,17$, & $1,2,3,4,10,13,14,17,19,21,2$ & $2,3,4,5,10,13,14,17,19,21$ \\
& $19,27,29,32,33,38,39,40$ & $3,24,25,26,27,28,30,34,38$ & $, 23,24,26,27,28,33,39$ \\
\hline Jumlah & 12 & 19 & 17 \\
\hline & $1,4,6,7,8,9,10,11,12,13,14$, & $5,6,7,8,9,11,12,15,16,18,20$ & $11,12,15,16,18,9,20,22,25$, \\
CDQ>0 & $15,16,18,20,21,22,23,24,25$ & $, 22,29,31,32,33,35,36,37$, & $29,30,31,32,34,35,36,37$, \\
& $, 26,28,30,31,34,35,36,37$ & 39,40 & 40 \\
\hline Jumlah & 28 & 21 & 23 \\
\hline
\end{tabular}

Menurut Suwarna (2013) jumlah rata-rata tingkat miskonsepsi yang terjadi pada peserta didik dalam memilih jawaban, alasan atau keduanya tergolong sedang yaitu sebesar $40 \%$, meskipun demikian miskonsepsi harus segera diperbaiki, karena akan mempunyai efek pada pembelajaran selanjutnya. Menurut Tambunan (2015), peserta didik yang mengalami miskonsepsi akan tetap bertahan pada konsep salah yang dianggapnya benar. Hal seperti itulah yang menyebabkan miskonsepsi bersifat stabil dan tahan lama. Jika miskonsepsi tidak diatasi akan berdampak pada pembelajaran selanjutnya. Hasil analisis miskonsepsi peserta didik dengan nilai CDQ secara garis besar juga disajikan dalam Gambar 1.

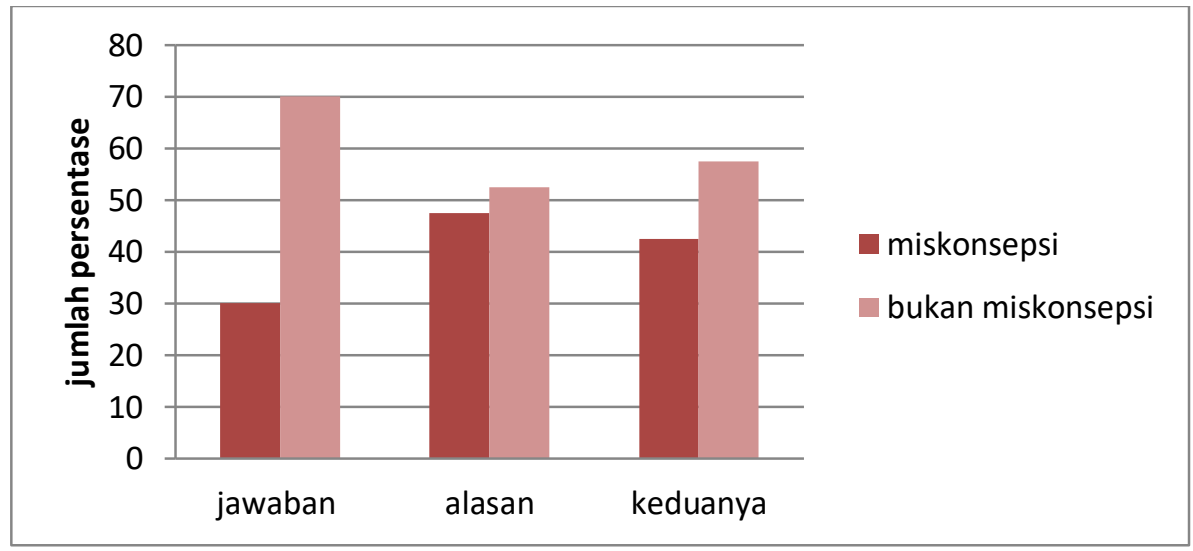

Gambar 1. Hasil Analisis Miskonsepsi Peserta Didik Dengan CDQ

Berdasarkan Gambar 1 menunjukkan bahwa miskonsepsi yang dialami peserta didik paling banyak terjadi pada tingkat alasan yaitu sebesar $47,5 \%$ pada tingkat alasan. Miskonsepsi yang dialami peserta didik sedang terjadi pada tingkat keduanya (jawaban dan alasan) yaitu sebesar 42,5\% pada tingkat keduanya. Miskonsepsi yang 
dialami peserta didik paling rendah terjadi pada tingkat jawaban yaitu sebesar $30 \%$ tingkat jawaban. Data tersebut menunjuk-kan rata-rata peserta didik menjawab salah lebih yakin dibandingkan peserta didik yang menjawab dengan benar. Peserta didik cenderung tidak dapat membedakan apa yang mereka pahami dan apa yang mereka tidak pahami dengan benar.

Miskonsepsi yang ditemukan dari hasil jawaban peserta didik diantaranya: gugus koenzim sebagai molekul organik yang terikat kuat dan stabil dalam protein sehingga dapat membantu proses katalisis suatu reaksi enzimatis, enzim mempunyai sifat sebagai biokatalisator, yaitu mempercepat reaksi kimia dengan menaikkan energi aktivasi, ATP berperan sebagai sumber energi, fosfogliseraldehid merupakan molekul sederhana dari pemecahan lemak yang diproses dalam siklus krebs, dan ATP sintase berperan sebagai sumber energi yang digunakan dalam fosforilasi oksidatif.

Soal four-tier multiple choice diagnostic test materi katabolisme yang telah dikerjakan peserta didik pada uji coba skala besar juga dilakukan analisis interpretasi hasil four-tier multiple choice diagnostic test untuk mengkategorikan peserta didik dalam kategori paham, tidak paham atau miskonsepsi. Rekapitulasi hasil analisis data interpretasi hasil four-tier mulitiple choice diagnostic test pada tiap indikator soal disajikan dalam Tabel 3.

Tabel 3. Hasil Analisis data interpretasi hasil four-tier mulitiple choice diagnostic test

\begin{tabular}{cccc}
\hline Kategori & Tertinggi (\%) & Terendah (\%) & Rata-rata (\%) \\
\hline Paham & 48,6 & 0 & 11,3 \\
Tidak Paham & 64,8 & 12,2 & 29,3 \\
Mis-konsepsi & 86,5 & 27 & 58,9 \\
\hline
\end{tabular}

Berdasarkan Tabel 3, menunjukkan bahwa peserta didik memahami konsep, tidak paham konsep dan miskonsepsi pada tiap butir soal. Persentase tertinggi pemahaman konsep peserta didik terdapat pada butir soal nomor 35 sebesar $48,6 \%$. Persentase terendah pemahaman konsep peserta didik memahami konsep terendah terdapat pada butir soal nomor $3,4,10,13,18,19,23,27,29,38$, dan 40 sebesar $0 \%$. Persentase tertinggi ketidakpahaman konsep peserta didik terdapat pada butir soal nomor 24 sebesar $64,8 \%$. Persentase terendah ketidakpahaman konsep peserta didik terdapat pada butir soal nomor 2,14, dan 35 sebesar 12,2\%. Persentase tertinggi miskonsepsi peserta didik terdapat pada butir soal nomor 4 sebesar $86,5 \%$. Persentase terendah miskonsepsi peserta didik terdapat pada butir soal nomor 9 dan 31 sebesar $27 \%$. Hasil analisis data interpretasi hasil four-tier mulitiple choice diagnostic test dapat dilihat pada Gambar 2. 


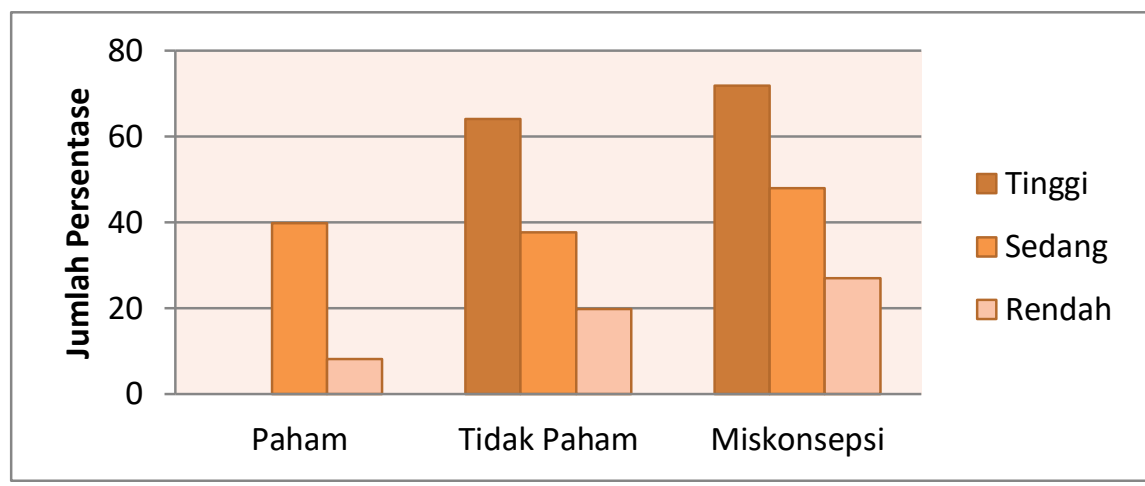

Gambar 2. Hasil analisis data interpretasi hasil four-tier mulitiple choice diagnostic test

Berdasarkan Gambar 2 menunjuk-kan bahwa Peserta didik tergolong memahami konsep pada kategori tinggi sebesar $0 \%$, hal ini menunjukkan bahwa tidak ada peserta didik yang benar-benar memahami materi sub katabolisme. Peserta didik tergolong memahami konsep pada kategori sedang sebesar 29,9\%, dan rendah sebesar $8,1 \%$, hal ini menunjukkan sebagian besar peserta didik mempunyai pemahaman rendah pada materi katabolisme.

Peserta didik tergolong tidak memahami konsep pada kategori tinggi sebesar $64,2 \%$, sedang sebesar $37,7 \%$, dan tinggi sebesar $19,9 \%$. Hal ini menunjukkan bahwa sebagian besar peserta didik belum menguasai dengan baik materi sub katabolisme pada butir soal yang diujikan. Peserta didik yang tidak memahami konsep ini diketahui dari tingkat keyakinan rendah yang diberikan peserta didik dalam memberikan jawaban dan alasan, yaitu pada skala 1 (hanya menebak), skala 2 (sangat tidak yakin), atau skala 3 (tidak yakin).

Peserta didik mengalami miskonsepsi pada kategori tinggi sebesar $71,9 \%$, sedang sebesar $48 \%$, dan tinggi sebesar $27 \%$. Hal ini menunjukkan bahwa sebagian besar peserta didik mengalami miskonsepsi sebesar $71,9 \%$ dari seluruh butir soal materi katabolisme yang diujikan. Peserta didik juga mengalami miskonsepsi kategori sedang sebesar $48 \%$ dari jumlah butir soal yang diujikan. Peserta didik mempunyai tingkat kepercayaan yang sama pada suatu konsep yang tidak sesuai dengan konsep ilmuwan. Tingkat keyakinan mereka semakin tinggi pada konsep yang salah ketika teman-teman mereka juga sama-sama mempunyai tingkat keyakinan yang sama tingginya terhadap konsep tersebut.

Hasil wawancara dengan peserta didik saat pra riset, menunjukkan miskonsepsi tersebut dikarenakan kurangnya pemahaman peserta didik itu sendiri, konteks pembelajaran, dan buku (sumber belajar) yang digunakan. Penelitian ini mengungkapkan terdapat 7 sub pokok bahasan dan 18 indikator butir soal yang terdeteksi adanya miskonsepsi yang dialami peserta didik. Hasil penelitian ini dapat dijadikan sebagai pedoman guru untuk mengetahui kesulitan yang dialami peserta didik dan memperbaiki pembelajaran, sehingga guru dapat menanggulangi dan mengatasi miskonsepsi yang dialami peserta didik. 


\section{SIMPULAN DAN SARAN}

Produk akhir yang dihasilkan berupa instrumen soal tes pilihan ganda empat tingkat dengan materi katabolisme meliputi kisi-kisi, naskah soal, petunjuk pengisian soal, petunjuk pengisian lembar jawaban, lembar jawaban, kunci jawaban, pedoman penskoran, dan pedoman interpretasi hasil. Soal tes terdiri dari empat tingkatan, yaitu tingkat pertama berupa soal dengan empat pilihan pengecoh dan satu jawaban benar, tingkat kedua berupa pilihan tingkat keyakinan jawaban, tingkat ketiga berupa tiga pilihan pengecoh dan satu alasan benar disertai satu alasan terbuka, tingkat keempat berupa pilihan tingkat keyakinan alasan.

Instrumen soal tes yang dihasilkan mempunyai produk akhir berjumlah 37 butir soal dan memiliki reliabilitas tinggi dengan nilai koefisien Alpha 0,894. Berdasarkan kategori tingkat kognitif yang berpedoman pada taksonomi Bloom, dari 37 butir soal produk akhir terdapat 6 soal C-1, 7 soal C-2, 8 soal C-3 dan 16 soal C-4. 37 butir soal produk akhir mempunyai 4 butir soal mudah, 24 butir soal sedang dan 9 butir soal susah dengan daya beda baik sebanyak 33 butir soal dan daya beda cukup sebanyak 4 butir soal. Berdasarkan penilaian validator instrumen soal tes yang dikembangkan cukup valid digunakan dengan persentase skor rata-rata 78,3\%.

Miskonsepsi (kesalahan dalam memahami konsep) yang ditemukan pada peserta didik berdasarkan nilai CDQ terdapat pada 18 indikator soal, diantaranya yaitu (1) gugus koenzim sebagai molekul organik yang terikat kuat dan stabil dalam protein sehingga dapat membantu proses katalisis suatu reaksi enzimatis, (2) enzim mempunyai sifat sebagai biokatalisator, yaitu mempercepat reaksi kimia dengan menaikkan energi aktivasi, (6) ATP berperan sebagai sumber energi, (7) fosfogliseraldehid merupakan molekul sederhana dari pemecahan lemak yang diproses dalam siklus krebs, (15) ATP sintase berperan sebagai sumber energi yang digunakan dalam fosforilasi oksidatif, (16) tidak adanya oksigen dalam transpor elektron membuat proses transpor elektron berjalan tidak sempurna, (17) hasil transpor elektron berupa 32 ATP dan $\mathrm{H}_{2} \mathrm{O}$ terbentuk dari pelepasan dan penerimaan elektron oleh karbon, (18) oksidasi ion oleh NADH terhadap asam piruvat terjadi di dalam fermentasi alkohol saja. Miskonsepsi tertinggi ditemukan pada pilihan alasan dan miskonsepsi terendah ditemukan pada pilihan jawaban.

Berdasarkan hasil penelitian, saran yang diberikan diantaranya adalah diperlukan evaluasi untuk menyelidiki kemungkinan miskonsepsi yang dialami guru. Sehingga diperlukan tindak lanjut untuk mengatasi miskonsepsi yang terjadi, seperti dengan melakukan pembelajaran remidial pada sub materi yang terdeteksi adanya miskonsepsi. Selain itu evaluasi terhadap buku atau sumber belajar yang dipakai oleh peserta didi juga perlu dilakukan.

\section{RUJUKAN}

Arikunto, S.(2013). Dasar-Dasar Evaluasi Pendidikan. Jakarta: Bumi Aksara.

Caleon, Imelda S. \& Subramaniam, R. (2010). Do Students Know What They Know and What They Don't Know? Using a Four-Tier Diagnostic Test to Assess the 
Nature of Students' Alternative Conceptions. Research in Science Education. 40(3), 313-337.

Fariyani, Qisthi, dkk. (2015). Pengembangan Four-Tier Diagnostic Test Untuk Mengungkap Miskonsepsi Fisika Siswa SMA Kelas X. Journal of Innovative Science Education .4(2), 41-49.

Gall,M. D., Gall, J.P. \& Borg, W.R. (2003). Educational Research and Education Sevent Edition. USA: Pearson Education Inc.

Gurel, Derya Kaltakci, dkk. (2015). A Review and Comparison of Diagnostic Instruments to Identify Students' Misconceptions in Science. Eurasia Journal of Mathematics, Science \& Technology Education . 11(5), 989-1008.

Mustaqim, Tri Ade, dkk. (2014). Identifikasi Miskonsepsi Siswa Dengan Menggunakan Metode Certainty Of Response Index (CRI) Pada Konsep Fotosintesis Dan Respirasi Tumbuhan. Jurnal EDUSAINS. 4(2), 146-152.

Rahmatan, H \& Liliasari. (2014). Pengetahuan Awal Calon Guru Biologi Tentang Konsep Katabolisme Karbohidrat (Respirasi Seluler). Jurnal Pendidikan IPA Indonesia.1(1), 91-97.

Sugiyono. (2015). Metode Penelitian Pendidikan Pendekatan Kualitatif, Kuantitati, dan $R \& D$. Bandung: Alfabeta.

Sukmadinata, Nana Syaodih. (2011). Landasan Psikologi Proses Pendidikan. Bandung: Rosdakarya Offset.

Suparno, Paul. (2005). Miskonsepsi \& Perubahan Konsep Dalam Pendidikan Fisika. Jakarta: Gramedia Widiasarana Indonesia.

Suwarto. (2010). Pengembangan The Two-Tier Diagnostic Tests Pada Bidang Biologi Secara Terkomputerisasi. Jurnal Penelitian dan Evaluasi Pendidikan, 14 (2), 206224.

Suwarto. (2013). Pengembangan Tes Diagnostik dalam Pembelajaran: Panduan praktis bagi pendidik dan calon pendidik. Dalam Widodo (Ed.). Yogyakarta: Pustaka Belajar.

Syah, Muhibbin. (2014). Telaah Singkat Perkembangan Peserta Didik. Jakarta: Rajawali Pers.

Tambunan, Twentyna Junita. (2015). Analisis miskonsepsi siswa pada materi metabolisme di kelas XII IPA SMA Swasta Nusantara Lubuk Pakam Tahun Pembelajaran 2014/2015. Skripsi. Medan: Jurusan biologi. FMIPA. Universitas Negri Medan.

Tekkaya, Ceren. (2002). Misconceptions As Barrier To Understanding Biology. Journal of Universitas Hacettepe Ankara. Edisi 23, 259-266.

Wijaya, M. H., Surato, Aminuddin H.P. (2013). Pengembangan Tes Diagnostik Mata Pelajaran IPA SMP. Jurnal Penelitian dan Evaluasi Pendidikan,17 (1), 19-36. 